\title{
Improving Learning Motivation Through Virtual Ice Breaking in Online Learning
}

\section{Qoyim Qonita Hanggrahini}

Universitas Sebelas Maret

qoyimqonita@student.uns.ac.id

\section{Article History}

received 30/4/2021

revised 30/5/2021

accepted 30/6/2021

\begin{abstract}
Learning motivation in online learning needs to be improved to get to a quality school. Teachers attempted to focus the attention of students so that they had a sense of joy when they were participating in online learning, so students had the ability to focus their minds and be actively involved in online learning. Games or activities that serve to change the frozen atmosphere into fun are called ice breaking. The aims of this research are (1) To improve learning motivation in online learning (2) To improve online learning by using virtual ice breaker.

Keywords: Online learning, Ice breaking, virtual.
\end{abstract}

\section{Abstrak}

Motivasi belajar dalam pembelajaran daring perlu ditingkatkan untuk menuju sekolah yang berkualitas. Pendidik berupaya pemusatan perhatian peserta didik supaya memiliki rasa gembira saat mengikuti pembelajaran daring, peserta didik supaya memiliki kemampuan untuk memfokuskan pikiran dan terlibat secara aktif dalam pembelajaran daring. Permainan atau kegiatan yang berfungsi untuk mengubah suasana kebekuan menjadi menyenangkan disebut ice breaking. Tujuan penelitian ini adalah (1) Untuk meningkatkan motivasi belajar dalam pembelajaran daring (2) Untuk meningkatkan pembelajaran daring dengan menggunakan ice breaking virtual.

Kata Kunci: Pembelajaran daring, Ice breaking, virtual. 


\section{PENDAHULUAN}

Pandemi yang mewabah di Indonesia mengakibatkan terjadinya pembelajaran jarak jauh atau belajar di rumah, Kondisi tersebut banyak dikeluhkan oleh peserta didik dan guru. Peserta didik tidak serius dalam pembelajaran dan sering ditinggal pergi, tidak aktif pada PJJ (Pembelajaran Jarak Jauh), tidak mengerjakan tugas. Peserta didik mengalami ken dala dalam pembelajaran jarak jauh yaitu keadaan di rumah antar-interaksi keluarga sering mengganggu pembelajaran. Koneksi internet, masalah paket data, tugas lebih banyak dari pada penjelasan, sulit bertanya pada guru, penjelasan terasa terlalu susah, banyak godaan, jauh dari teman. Permasalahan di atas tentu mengganggu kelancaran belajar, yang akhirnya menimbulkan siswa malas untuk belajar dalam jaringan atau daring.

Pembelajaran daring yang monoton akan cepat membosankan. Ketika pikiran tidak fokus pada pembelajaran, maka dibutuhkan upaya pemusatan perhatian supaya peserta didik memiliki rasa gembira pada saat mengikuti proses pembelajaran daring, peserta didik akan memiliki kemampuan memfokuskan pikiran dan terlibat aktif dan interaktif dalam proses pembelajaran. Dengan demikian penting bagi pendidik untuk menguasai berbagai pembelajaran, salah satunya teknik ice breaking dalam upaya untuk terus menjaga konsentrasi belajar peserta didik dan meningkatkan motivasi belajar.

Pembelajaran daring dilakukan secara virtual yaitu pembelajaran yang berbasis internet. Istilah ini sudah tidak asing semenjak terjadinya pandemi yang melanda dunia khususnya Indonesia. Pembelajaran secara virtual dapat dikatakan berhasil jika tujuan pembelajaran yang telah ditentukan tercapai. Capaian tujuan pembelajaran tersebut terlihat dari hasil yang diperoleh peserta didik serta keantusiasan dalam mengikuti pembelajaran. Menurut Nana Sudjana (2010) persyaratan utama dalam proses belajar-mengajar adalah perhatian dan motivasi. Hasil belajar yang akan dicapai siswa tidak akan optimal tanpa perhatian dan motivasi. Maka dari itu perlu meningkatkan motivasi belajar peserta didik beberapa cara agar tujuan pembelajaran dapat tercapai. Motivasi belajar faktor psikis yang bersifat nonintelektual dan memiliki peranan yang khas adalah hal perbuatan gairah semangat untuk belajar dan merasa senang. Lutffi menyampaikan dalam Sunarto (2012) atau pemecah kebekuan adalah kegiatan kegiatan yang dilakukan oleh pendidik membuat suasana kelas menjadi akrab dan menyenangkan guna menyegarkan suasana. Kegiatan yang dilakukan pendidik tidak dibatasi pada keharusan membuat kegiatan yang bersifat games atau permainan juga bisa dilakukan dengan kegiatan yang lain, yang penting menghasilkan suasana segar dan gembira.

Harapan diadakannya ice breaking secara virtual adalah proses belajar lebih efektif. Jika peserta didik dalam keadaan gembira maka pencapaian hasil belajar pun lebih baik juga sebagai penyalur pesan dalam tujuan pembelajaran. Peralihan situasi dari yang membuat ngantuk, menjenuhkan, membosankan, dan tegang menjadi rileks, bersemangat, tidak mengantuk, lebih perhatian dan muncul rasa tertarik untuk mendengarkan orang lain yang berbicara di depan kelas atau ruang pertemuan merupakan tujuan Ice Breaking. Setelah beberapa menit materi pembelajaran dimulai terjadilah penurunan memori terhadap materi pelajaran. Saat itulah merupakan saat yang tepat untuk melakukan ice breaking. Berdasarkan uraian tersebut permainan penyegar (ice breaking) adalah suatu kegiatan yang dilakukan untuk mencairkan suasana pembelajaran yang menyegarkan, aktif, menyenangkan, dan membangkitkan motivasi belajar lebih bergairah.

Berdasarkan uraian di atas ice breaking secara virtual dapat meningkatkan motivasi peserta didik saat pembelajaran daring dengan suasana pembelajaran yang menyegarkan, aktif, menyenangkan, dan membangkitkan motivasi belajar lebih bergairah dengan hasil belajar yang akan dicapai siswa akan optimal melalui kegiatan 
Volume 9 Nomor 1 Tahun 2021

yang bersifat games atau permainan juga bisa dilakukan dengan kegiatan yang lain, yang penting menghasilkan suasana segar dan gembira.

\section{HASIL DAN PEMBAHASAN}

Kegiatan guru untuk memikirkan serta mengupayakan terjadinya kosistensi antara aspek aspek komponen pembentukan sistem pembelajaran merupakan strategi pembelajaran (Anitah Sri, 2014). Guru menggunakan stategi dalam pembelajaran. Strategi pembelajaran pada tahap perencanaan mengacu dalam upaya secara strategis yaitu memilih, menetapakan, dan merumuskan komponen-komponen pembelajaran serta mengatualisasikan berabagai gagasan yang telah dirancang dengan memodifikasi dan memberikan perlakuan yang selaras dan bersiasat sehingga komponen-komponen pembelajaran berfungsi mengembangakan potensi peserta didik dalam mewujudkan pembelajaran yang baik seta mampu mencapai tujuan pembelajaran sehingga teknik pembelajaran yang baik untuk diterapkan kepada para peserta didik dalam penerapannya.

Dengan demikian penting bagi para guru mengoptimalkan hal yang dapat membuat anak senang dalam belajar. Hal yang bisa dilakukan seorang guru menciptakan suasana yang menyenangkan yaitu dengan memasukan ice breaker dalam pembelajaran. Andi Wira Gunawan dalam Meity (2015) Tidak ada mata pelajaran yang membosankan, yang ada adalah suasana belajar yang membosankan dan guru yang membosankan. Goleman berkata Sunarto (2012) kapasitas syaraf untuk berfikir rasional mengecil ketika otak menerima tekanan atau ancaman. Otak dibajak pada tingkat emosional. MacLean dalam Sunarto (2012) saat otak pada situasi tertekan, maka otak akan pada mode kabur atau bertempur dan beroperasi pada tingkat bertahan hidup. Untuk menyegarkan otak upaya pengembangannya bisa dilakukan dengan bermain sambil belajar. Dengan bermain anak mempunyai kesempatan untuk berkreasi, menemukan sesuatu, berekspresi dan belajar dengan menyenangkan.

Abdul (2015) Ice Breaking yaitu kegiatan yang memiliki fungsi mengubah suasana kebekuan kelompok. Pendapat lain menyatakan ice breaker merupakan peralihan situasi dari yang membuat mengantuk, menjenuhkan membosankan, dan tegang menjadi bersemangat, tidak membuat mengantuk, rileks, serta ada perhatian dan rasa senang untuk mendengarkan orang yang berbicara di ruang pertemuan. Ice breaker merupakan cara menciptakan suasana kondusif. "Penyatuan" pola pikir ke satu titik perhatian adalah yang membuat suasana menjadi terkondisi untuk fokus dan dinamis. Salah satu solusi yang tepat menjadikan pembelajaran menjadi menyenangkan adalah guru mengembangkan ice breaker saat pembelajaran. Ice breaker dalam dunia pendidikan jarang dilakukan oleh guru. Budiman (2016:79) menyatakan "Ice breaker merupakan sebuah aktivitas kecil pada suatu acara yang memiiki tujuan audiens merasa nyaman dalam lingungannya. Menurut Abduh (2011) Menggunakan ice breaking pada proses pelajaran terkadang kita melihat timbulnya suasana yang tidak mendukung hingga menyebabkan tidak tercapainya tujuan dari pembelajaran. Suasana yang dimaksud adalah kaku, dingin, atau beku sehingga pembelajara saat itu menjadi kurang nyaman. Sering dikatakan bahwa ice breaker pemecah suasana yang kaku atau sebagai pemecah kebekuan. Sunarto (2012:3) menyatakan "Ice breaker dimaksudkan untuk membangun suasana belajar yang dinamis, penuh semangat, dan antusias". Suasana yang menyenangkan dan kondusif sangat dibutuhkan peserta didik dalam belajar salah satunya adalah untuk membawa siswa ke dalam zona nyamannya belajar. Penggunaan ice breaker dalam pembelajaran juga dapat membantu dalam menciptakan suasana pembelajaran menjadi lebih bermakna. Yang dapat dilakukan guru yaitu bercerita humor, mendengarkan musik atau memutarkan video. Pilihan tersebut bisa dilakukan oleh guru dengan mempertimbangkan kemampuan guru dan sarana yang tersedia. 
Penggunaan ice breaker sangatlah bermanfaat yang baik kepada guru dalam pembelajaran. Sunarto (2012) mengungkapkan terdapat beberapa kebermanfaatan dari penggunaan ice breaker pada proses pembelajaran yaitu (1) Bisa dipelajari oleh setiap orang tanpa membutuhkan keterampilan tinggi, (2) Alat menciptakan nuansa keakraban dan kegembiraan antarsiswa, maupun antara guru dan (3) menciptakan suasana pendidikan menyenangkan dan bermakna. Peranan ice breaker pada proses pembelajaran bermanfaat untuk meningkatkan motivasi belajar peserta didik.

Fiyati (2010) Beberapa anak yang ditemukan masih salah, disuruh maju dan diberikan hukuman sederhana yang menghibur. Antusiasme peserta didik mulai muncul dan mereka mulai menerima peneliti sebagai guru mereka. Atmosfir di kelas yang biasanya cenderung hening dan membosankan menjadi ramai dan responsif. Sadirman (2013) Manusia adalah makhluk sosial, makhluk yang tidak bisa hidup sendiri tanpa dukungan atau bantuan dari individu lainnya. Karena itu terjadi saling ketergantungan antar individu satu dengan lainnya. Mereka saling berinteraksi dan berproses, yang pada akhirnya melahirkan penyesuaian di antara mereka. Penyesuaian dapat terjadi karena adanya saling pengertian dan pemahaman terhadap fungsi masing-masing, yang terwujud dari penghargaan terhadap kemampuan dan keahlian yang dimiliki. Karena adanya tergantungan antar individu satu dengan yang lainnya, maka manusia harus berinteraksi Sejalan dengan hal tersebut penelitian yang dilakukan oleh Ambini (2016) yang menunjukkan bahwa pemberian ice breaker dapat meningkatkan aktivitas siswa dan motivasi belajar siswa kelas V SDN Monggang.

\section{SIMPULAN}

Kegiatan ice breaking dapat diaplikasikan dengan kegiatan bercerita humor, mendengarkan musik atau memutarkan video. Kegiatan ice breaking meningkatkan motivasi peserta didik saat pembelajaran daring yang monoton dan membosankan. Ice breaking dapat memfokuskan peserta didik pada pembelajaran, sehingga peserta didik memiliki rasa gembira pada saat mengikuti proses pembelajaran daring, peserta didik akan memiliki kemampuan memfokuskan pikiran dan terlibat aktif dan interaktif dalam proses pembelajaran. Ketika pembelajaran daring ice breaking virtual dapat meningkatkan motivasi peserta didik saat kegiatan belajar mengajar berlangsung.

\section{DAFTAR PUSTAKA}

Abduh, Muhammad. 2010. Menciptakan Pembelajaran yang Menyenangkan. Jakarta. Hhtp://www.MuhammadAbduh.com/

Abdul. 2015. Mempelajari Ice Breaking Dalam Belajar. Jakarta: PT. Bimi Santara

Ambini, R. 2016. "Meningkatkan Motivasi Belajar IPS melalui Pemberian Ice Breaker pada Siswa Kelas V SDN Monggang". Basic Education. Vol. 5, No. 29

Anitah Sri. 2014. Strategi Pembelajaran di SD, Jakarta: Pusat Penerbitan UniversitasTerbuka.

Budiman, A. 2016. Panduan Menjadi MC Humoris yang Memukau dan Menghibur Audience. Yogyakarta: Araska

Fiyati, Adinda. 2010. Macam-macam Ice Breaking. https://adindafiya.wordpress.com/ 2010/08/25/macam-macam-ice-breaking. (4 Oktober 2018)

H. Idris Meity. 2015. Strategi Pembelajaran yang Menyenagkan. Jakarta: Luxima.

Nana Sudjana. 2010. Cara Belajar Siswa Aktif Dalam Proses Belajar Mengajar, Bandung: Sinar Baru Algensindo.

Sardiman. 2013. Interaksi dan Motivasi Belajar Mengajar. Jakarta: Raja Grafindo Persada.

Sunarto.2012. Icebreaker Dalam Pembelajaran Aktif.Surakarta : Cakrawala Media 